\title{
German Greens go cold on nuclear fusion
}

Munich

The Green Party, the junior partner in Germany's ruling coalition, is urging the government to slam the brakes on research into nuclear fusion. It wants Germany to cut its commitments to the national fusion research programme, and to withdraw support for the planned International Thermonuclear Experimental Reactor (ITER).

The Green Party's strategy paper on energy research, published last month, recommends that nuclear research be restricted to areas such as reactor safety. It says that money earmarked for research on new nuclear fusion and fission technologies should be used to increase the efficiency of technologies for renewable energy sources, such as wind and solar energy.

The German fusion community is reacting nervously to such suggestions, aware that energy policy is a core issue for the Greens, and that fusion research has still to demonstrate its feasibility. The Greens have already achieved the government's commitment to one of their major goals - phasing out atomic energy in Germany by 2019 - so the party's position on other energy-related issues has obvious political weight.

"Energy from nuclear fusion will only be available in half a century, if at all," says HansJosef Fell, the Greens' parliamentary spokesman on research, and a member of the parliamentary committee on science and technology. "Given the urgency of replacing fossil and atomic energy by new climatefriendly and safe energy sources, it would be fatal to put trust in such a vague and distant option," he says.

ITER, which was designed to study the physics of burning plasma and the engineering problems related to a future power-generating fusion reactor, is a proposed 3.5 billion euro (US $\$ 3.1$ billion) collaborative project between Europe, Russia and Japan. Its design outline was slimmed down considerably last year, after the United States, concerned about the project's high costs and scientific uncertainty, withdrew support (see Nature 402, 570; 1999).

The Greens would like Germany to follow suit. They want the government to urge the European Commission not to co-fund ITER in its sixth Framework programme of research (FP6), due to start in 2003. Discussions about FP6 will begin this summer.

But the German government has given no signs that its support for fusion research is waning. The research minister, Edelgard Bulmahn, and her state secretary for research, Wolf-Michael Catenhusen, are known for their pragmatic views on scientific projects. It appears unlikely that Bulmahn will take the lead in any possible European opposition to ITER when the European

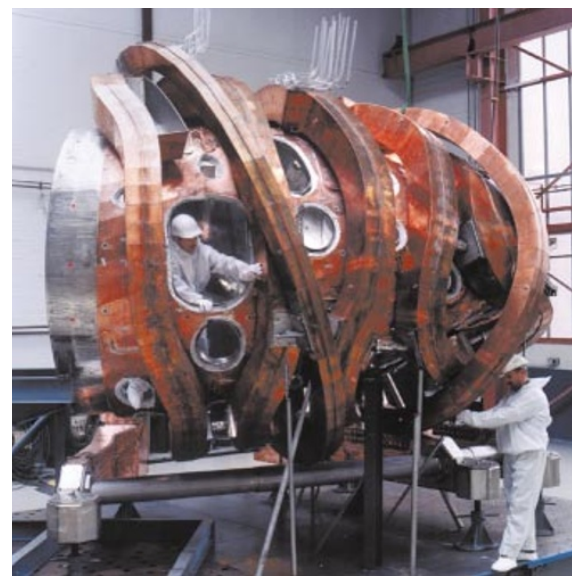

Uncertain future: the Wendelstein 7-X fusion reactor would be redesigned under Green plans.

science ministers meet next year to decide about future support for the project.

Fusion scientists in Germany hope that pragmatism will also thwart another of the Greens' proposals: a major redesign of the Wendelstein-7X, an experimental fusion reactor being built in Greifswald in eastern Germany by the Max Planck Institute for Plasma Physics (IPP).

The 'stellarator' reactor, which cost DM300 million (US\$135 million), is eastern Germany's largest research facility. It is designed for a plasma-physics experiment using superconducting coils to produce the magnetic field necessary for sustained burn
- an unsolved problem with regard to a functioning fusion power plant.

The Greens say the reactor should be built as planned, but that it should be used almost exclusively for research in conventional lowtemperature plasma physics and on a few possible spin-offs from nuclear fusion research.

Alexander Bradshaw, scientific director of the IPP, calls the idea "scientifically and economically absurd, and technically impossible". Bradshaw says he is particularly disappointed because he is sympathetic to Green policies in areas such as climate protection, and appreciates their generally positive attitude towards basic research.

"The Greens can prosper without hitting out at fusion research," says Bradshaw. He adds that the US decision on ITER is irrelevant, as overall US spending on fusion technologies is increasing (see Nature 400, 394; 1999).

Bradshaw is confident that the government will base its energy research policy on proposals made last year by the Wissenschaftsrat, Germany's influential science council, rather than by the Greens. The Wissenschaftsrat recommended that all energy options should be left open, and called for a 30 per cent increase in energy research budgets (see Nature 397,375, 1999).

The Greens' proposals will be discussed further in the federal parliament's committee on research.

Quirin Schiermeier

\section{Canada's plans for neutrons stall}

\section{Washington}

Canada's leading role in neutron scattering is under threat, according to Canadian physicists. An ambitious plan to construct a world-class neutron-scattering facility at Chalk River, Ontario, could collapse unless funds are forthcoming from the government this year, they claim.

Government ministers have approved construction of the Can $\$ 400$ million (US\$270 million) facility in principle. But money to start the project was not included in this year's budget when it was announced in February (see Nature 404, 8; 2000).

"We don't understand why it didn't appear" in the budget, says Bill Buyers, a senior scientist on the twenty-strong team behind the proposal.

Now project backers are hoping that the government will announce support for the facility this summer, possibly as part of a 'mini-budget' in the run-up to the next general election. "I'm very optimistic that it will get funded," says Buyers.
A replacement for the 43-year-old National Reactor Universal (NRU), the proposed Canadian Neutron Facility (CNF) would have eleven experimental beamlines and space to add another twelve. It would be built on the same Chalk River site as the NRU, which is expected to close when its operating licence expires in December 2005.

Scientists had hoped that the six-year construction of the CNF would start last year, avoiding a 'neutron gap' when the old reactor shuts down. Canada is already building two medical isotope reactors to replace the NRU, which is the largest source of medical isotopes in the world, accounting for 70 per cent of the total market.

The CNF would be built jointly by Atomic Energy of Canada Limited (AECL) and the National Research Council of Canada. The reactor would serve both as a source of neutrons for scientific research and as a testbed for fuel rods and other nuclear reactor components required by AECL, whose CANDU (Canadian deuterium 


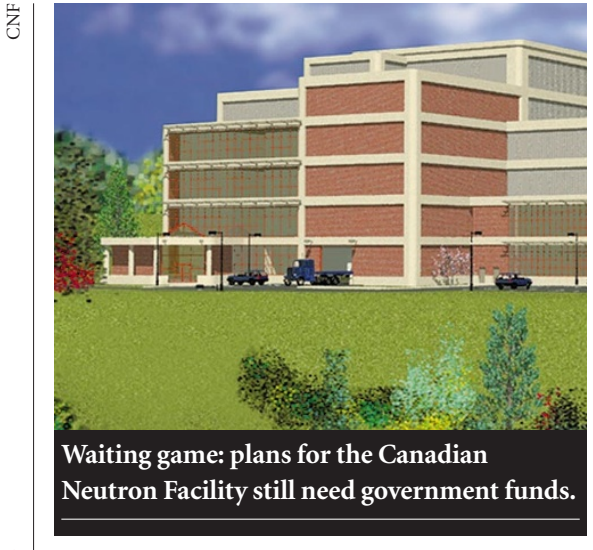

- uranium) designs for nuclear power stations have had some export success.

The double use of the facility means that its fate rests not just on the scientific case for a neutron facility, but also on the perceived importance of AECL's power reactor development programme at a time when few nuclear power stations are being built anywhere in the world.

"The dual use thing is a double-edged sword," says Thom Mason, a Canadian who is leading the project to build a $\$ 1.3$ billion neutron source at the Oak Ridge National Laboratory in the United States. "The case for neutron scattering is accepted, but the decision hinges on the future of CANDU, and that is totally decoupled from the scientific community's need for neutrons."

Mason is a strong supporter of the Canadian project. But if lack of funding causes the Canadian team to disintegrate, progress at the US facility, together with a new target chamber at ISIS in the United Kingdom and an imminent decision to build a neutron source in Australia, could all attract people away from Canada.

The $\mathbf{3 0 0}$ or so Canadian researchers who use neutrons say that failure to fund the facility will cause Canada to lose its long-standing leadership in neutron scattering, for which Canadian physicist Bertram Brockhouse won a Nobel Prize in 1994. "Neutron sources in the United States are heavily oversubscribed - we can't get beamtime there," says Buyers.

Researchers see the CNF as completing an important trio of national scientific facilities, together with Triumph, a particle accelerator in British Columbia, and the Canadian Light Source, a synchrotron light source being built at Saskatoon in the province of Saskatchewan.

But the CNF hasn't received financial support from the province of Ontario. And, ironically, the fact that the province is overwhelmingly loyal to the Liberal party of Jean Chretien, the Canadian prime minister, may actually reduce pressure on him to fund construction of the facility.

Colin Macilwain

\section{US reforms rules for telling public about GM food}

\section{Washington}

The Clinton administration has announced a series of regulatory changes and research proposals intended to shore up public confidence in the government's supervision of genetically modified (GM) food.

The Food and Drug Administration (FDA) will in future require companies that wish to introduce any new transgenic food to provide notice and supporting scientific research 120 days in advance. This information will then be placed on the Internet for public inspection. At present, companies submit this information on a voluntary basis, and it is not automatically made available to the public.

The FDA will also develop guidelines for the voluntary labelling of GM food, and will permit producers of food containing no GM organisms to label it as such.

But the changes, which were announced last week by the White House in conjunction with the FDA, the US Department of Agriculture (USDA) and the Environmental Protection Agency (EPA), did not include any mandatory requirement for the labelling of GM foods.

Although widely expected, this omission led most environmental groups to reject the changes, which they branded as cosmetic. Farming and industry groups, meanwhile, warmly welcomed the announcement. The National Corn Growers Association, which represents most large maize farmers, said the changes matched its own policy and position, as stated during public hearings conducted by the FDA last autumn (see Nature 402, 571;2000).

Farmers and the agricultural biotechnology industry have been pressing the government to make such changes, in the hope that they will strengthen US public confidence in GM food. GM foods are already ubiquitous in the food chain in the United States, where around half of this year's soybean crop and one-third of the maize will be transgenic.

The industry is concerned that European rejection of the technology will spill over into the United States, where GM crops were introduced after extensive scientific review but minimal public debate.

The USDA, FDA and EPA also pledged to coordinate their research programmes on the safety and risk assessment of agricultural biotechnology, although the amount of additional money to be made available for this was not specified. The USDA also said it will create standards to certify the various testing procedures that are available to establish whether foods contain GM organisms.

The White House Office of Science and Technology Policy and the Council of Environmental Quality said that they would conduct a further six-month study on the regulation of agricultural biotechnology. Under a long-standing arrangement, the FDA, EPA and USDA share responsibility for this regulation, depending on the intended function of the genetic modification.

Colin Macilwain

\section{Italian genomics boost retained}

\section{Munich}

In Italy, scientific initiatives tend to change with governments. But prime minister Giuliano Amato's new administration has retained a plan to launch strategic research programmes in human genomics and neuroscience.

Only days before the previous government fell last month, it issued a decree setting up two national committees to define the strategies. The decree was the brainchild of Vincenzo Sica, undersecretary of state for research, who has been reappointed to his position.

The committees, which met for the first time earlier this week, will put forward both scientific and financial proposals. If all goes according to Sica's plan, these will be worked into next year's research budget.
Sica hopes that substantial sums of money will start to flow early next year. "We'll need at least IL100 billion [US\$46 million] per year, and probably a lot more," he says.

Given the unpredictability of Italian politics - and the infighting at the ministry over the control of any genomics programme - this timetable may be a little optimistic. But if it works it will give Italian biology, long hampered by underfunding and poor management, a shot in the arm.

"Like all areas of biomedicine, the small amounts of funding available to neuroscience research are distributed thinly across a large number of research groups, and not strategically coordinated," says Piergiorgio Strata, professor of 